\title{
9. THE CONCEPT OF NATURE AND ITS APPLICATIONS IN THE LEGAL, MUSICAL AND EDUCATIONAL FIELDS
}

Flavia Marisi $^{82}$

\begin{abstract}
The concept of nature changed over time, modifying the relationship between nature and man: in some cultures man and nature are considered as deeply connected, in others definitely separated. The leading ideas about nature are reflected in work pertaining to the legal, musical and educational fields. This study provides insights into these issues, trying to highlight specific analogies which connect the concept of nature and its application in the cited fields.
\end{abstract}

Key words: aesthetic experience, anthropocentrism, consonant musical intervals, natural law, Notre Dame Law School, play

\section{The changing relationship between nature and man}

Nature is the whole of the physical world; it is also what exists outside of any human action. Man is in nature but he acts upon it, thereby emancipating himself of it: in some way, hit can be said that he is part and apart of nature.

Let us briefly focus on this point. Humans live in the realm of nature, and are constantly surrounded by it. This means that they are part of nature and interact with it. In effect, some oriental religions, such as Hinduism and Buddhism, consider mankind and nature as so deeply connected that it is impossible to make clear distinctions. The air man breathes, the water he drinks, the food he eats, have a strong influence not only on his physical and psychic health, but also on his whole way of living and working. Living organisms are influenced by the peaks of solar activity, and the energy of distant cosmic bodies: although each organism has its own rhythmic beat, it also responds to the vibrations of the elemental forces of outer space, bringing itself into unity with their oscillations $^{83}$. Thus, nature shall be careful observed and respectfully studied, in order to unveil its secret rules.

In contrasts, Western culture usually emphasized the separation of man and nature, dividing the cosmos into two distinct parts. Man, characterized by subjectivity, feeling, logic reason and free will, is conceived as actively exploring nature in order to conquer it, whereas the latter may be conceived as menacing or at least passive ${ }^{84}$. Maybe remembering that the distant ancestors lived in fear of nature's destructive forces, and were often unable to obtain the merest necessities of subsistence, Western culture assumed a strong anthropocentric standpoint. Anthropocentrism is characterized by the following elements: i) man is the central or most significant fact of the universe; ii) he is

\footnotetext{
82 Doctoral Candidate, Ghent University from Ghent of Belgium, email: flavia.marisi@ugent.be

${ }^{83}$ Pablo Martìnez de Anguita (2012), Environmental Solidarity. How Religions can Sustain Sustainability, Routledge, New York, 92

${ }^{84}$ Chen Kuide, Man vs. Nature and Natural Man: One Aspect of the Concept of Nature in China and the West, in Tang Yi-Jie, Li Zhen, George F. McLean (eds.) (1989), Man and Nature: The Chinese Tradition and the Future, University Press of America, Lanham - New York - London, 131-141, 136
} 
the measure of all things; iii) the world is to be interpreted in terms of human values and experiences ${ }^{85}$. As a consequence, the direct and indirect interests of mankind are put at first, and nature is considered as something to be subjugated, dominated and exploited. According to this view, it was thought that the wilderness was to be tamed: forests were considered wild and hostile to civilization, and people tried to force them to retreat, increasing the area of arable land ${ }^{86}$.

This trend, already present in the ancient Judeo-Christian cultural system, was enhanced by the Renaissance humanism, which glorified man's ability to give a rational order to the natural realm, making use of logic precision. For instance, during the Renaissance, Italian gardens were conceived as the concrete realization of the classical ideals of order and beauty, aimed at man's pleasure ${ }^{87}$. Italian gardens were considered as an expression of the visible dominion of man's intelligence and spirit over the confusion of nature. In the early $18^{\text {th }}$ century English landscape gardens emerged, presented as places in which nature predominated. They were characterized by sweeps of gently rolling ground and water, against a woodland background with clumps of trees and outlier groves ${ }^{88}$. Although adhering to quite different viewpoints, both these conceptions envisaged nature as something in which architects and garden designers had to bring their own harmony, since the wild nature had to be organized and improved. Concluding this part, it can be affirmed that the relationship between man and nature was focused on by different thinkers, in diverse ages, showing divergent perspectives.

\section{Nature and natural in the early legal thinking}

In the course of time, the legal thinking reflected the leading ideas about nature, focusing on natural rights and natural law. Already in ancient Greece some thinkers posited the existence of natural law and thought about its implications ${ }^{89}$. The great classical dramatists wrote plays in which a distinction and consequently a conflict was shown between positive, man-made laws (ta dikaia), which vary in different states and at different times, and natural law (to dikaion). Both Aeschylus (525-458 B.C.), in his play Seven against Thebes, and Sophocles (490-405 B.C), in his play Antigone, focused on conflicts between brothers, each of whom thought that the other was acting unjustly: the one required allegiance to positive laws, and the other on the contrary invoked allegiance to the unfailing statutes of natural law, written in men's hearts ${ }^{90}$. Later, also the Stoics centered their reflection on nature, claiming that virtue is

\footnotetext{
${ }^{85}$ Jim Willis (2004), The Religion Book: Places, Prophets, Saints, and Seers, Visible Ink, Canton, 31

${ }^{86}$ Michael Williams (2006), Deforesting the Earth: From Prehistory to Global Crisis. An Abridgment, The University of Chicago Press, London, 145

${ }^{87}$ Yves-Marie Allain, Janine Christiany (2006), L'art des jardins en Europe, Citadelles and Mazenod, Paris, 132

${ }^{88}$ Tim Richardson (2007), The Arcadian Friends: Inventing the English Landscape Garden, Bantam Press, London - Toronto - Sydney - Auckland - Johannesburg, 26

${ }^{89}$ Michael Bertram Crowe (1977), The Changing profile of the Natural Law, Springer, New York, 4

${ }^{90}$ Ibidem, 6
} 
to live "in accordance with nature": with this term they meant the whole of nature, the $\operatorname{cosmos}^{91}$.

During the Roman Empire, Isidore, a sixth century ecclesiastical writer, affirmed that, whereas human "civil" laws consist in customs or human enactments, and may greatly differ from one another, natural law is common to all peoples in that it is possessed by an instinct of nature ${ }^{92}$. Also in the Middle Ages the term ius naturale meant the universal and immutable law taught by some capacity innate in human beings, and accessible to personal reflection. To this natural law the laws of human legislators, the customs of particular communities, and the actions of individuals ought to conform. Also Thomas Aquinas affirmed that natural law cannot be blotted out, and that human law is legitimate only if it is in line with natural law ${ }^{93}$. In the opinion of these scholars, the universal nature of man gives origin to the principle that there must be laws universally applicable. Conversely, the laws governing human affairs must derive from some objective and external reality, and not be subject to the arbitrary will of the ruler ${ }^{94}$. Concluding this part, it can be highlighted that, as some legal thinkers stressed in their works, due to the universal nature of man, there must be universally applicable laws.

\section{Nature and natural in the early music theory field}

Also some scholars in the musical field focused on the concepts of nature and natural, showing an interesting analogy to the views expressed by legal thinkers. Pythagoras is credited to have formulated the theory of consonance, discovering that consonant musical intervals correspond to simple numerical proportions: dividing the monochord according to the ratio $2: 1$ he obtained the octave, dividing it according to the ratio $3: 2$ he obtained the fifth, and dividing it according to the ratio $4: 3$ he obtained the fourth ${ }^{95}$. The same mathematical proportions governed, in the Pythagoreans' view, the whole universe: the planets moving through the heavens give off sounds, called the music of the spheres, which exemplify the perfect organization of nature on the largest scale ${ }^{96}$

In the $16^{\text {th }}$ century, Gioseffo Zarlino continued Pythagoras's reflection, dividing the monochord according to the following relations: 5:4, which obtained the major third, 6:5, which obtained the minor third, and 5:3, which obtained the major sixth ${ }^{97}$. Johannes von Kepler (1571-1630), in his Harmonice Mundi built forth on Zarlino's definition of consonance, proposing that consonances would only be obtained for numbers that can divide the circle

\footnotetext{
${ }^{91}$ Julia Annas (1993), The Morality of Happiness, Oxford University Press, New York, 159

${ }_{92}$ Peter Curzon (1993), Jurisprudence Lecture Notes, Cavendish Publishing Limited, London, 39

93 Thomas Aquinas (1988), Summa Theologica, trans. Fathers of the English Dominican Province, Hackett Publishing Co., Indianapolis, I-II, Q. 77, A. 2

${ }^{94}$ James A. Donald, Natural Law and Natural Rights, http://jim.com/rights.html (accessed on 19 October 2015).

95 David Creese (2010), The Monochord in Ancient Greek Harmonic Science, Cambridge University Press, Cambridge, 91

${ }^{96}$ Thomas Levenson (1994), Measure for measure: A musical history of science, Touchstone, New York, 24

${ }^{97}$ David Damschroder, David Russell Williams (1990), Music theory from Zarlino to Schenker. A Bibliography and Guide, Pendragon Press, Stuyvesant, 391
} 
following a procedure achievable with ruler and compass ${ }^{98}$. The French music theorist Marin Mersenne (1588-1648), who formulated rules governing vibrating strings, was the first to discern the nature of partials related to a fundamental note $^{99}$.

In 1701 Joseph Sauveur expounded in print the hugely important principle of the overtone series. Although he was not the first to observe that tones of the harmonic series are emitted when a string vibrates in aliquot parts, he gave a table expressing all the values of the harmonics within the compass of five octaves and thus brought order to earlier scattered observations ${ }^{100}$. Building on the previous discoveries, Jean-Philippe Rameau (1683-1764) affirmed that a physical object, such as the string of an instrument or a column of air, vibrates in several ways simultaneously, producing sounds corresponding to those parts of various lengths. As a result, the hearing of a sound always involves these other components, called harmonics, the first of which generate the eighth, the double fifth, the double octave and the third ${ }^{101}$.

According to him, it is the natural rules governing the resonant body that give an answer to the question of why certain combinations of sounds sound consonant. Therefore, the task of musicians is to combine musical sounds according to the universal principles determined by nature, replicating in their artworks the relationships between sounds established in nature. In fact, according to Rameau, it is only reproducing the rules that nature itself has established for the resonance of physical bodies, that a composer can develop a pleasant harmony, and a coherent melody ${ }^{102}$. Concluding this part, it can be pointed out that, according to early research, in order to develop enjoyable melodies and harmonies, musicians have to identify the natural rules of consonance and dissonance, and comply with them.

\section{Nature and culture in play and aesthetic experience}

A combination between natural law theory, music theory and music education was conceived in 1987 by some thinkers belonging to the Notre Dame Law School. In designing their "new natural law theory", Germain Grisez, Joseph Boyle, and John Finnis claimed that there are seven basic goods which are, at the same time, received as gifts of nature and parts of a cultural heritage, that is objects of human striving ${ }^{103}$. It is very likely that, in establishing these premises, these researchers implicitly alluded to a specific concept, according to which man is at the same time part of nature and playing a particular, distinct role, which distinguishes him from all other livings.

\footnotetext{
${ }^{98}$ H.F. Cohen (1984), Quantifying Music. The Science of Music at the First Stage of the Scientific Revolution, 1580-1650, Springer-Science + Business Media, Dordrecht, 33-34

${ }^{99}$ Ruth Katz (2009), A Language of its Own: Sense and Meaning in the Making of Western Art Music, University of Chicago Press, Chicago, 95, note 51

${ }^{100}$ Robert E. Maxham (1976), The contributions of Joseph Sauveur (1653-1716) to acoustics, Dissertation, University of Rochester, v. II, 1

${ }^{101}$ Jeremy Begbie (2013), Music, Modernity, and God. Essays in Listening, Oxford University Press, Oxford, 2013, 77

${ }^{102}$ Idem, 77-78

${ }^{103}$ Germain Grisez, Joseph Boyle, John Finnis (1987), Practical Principles, Moral Truth, and Ultimate Ends, "The American Journal of Jurisprudence", 32, 99-151, 107
} 
The seven basic goods are: life, knowledge, play, aesthetic experience, sociability or friendship, practical reasonableness, and religion. They are sought by humans for their own sake ${ }^{104}$, and are considered incommensurable, because none of them "can be analytically reduced to being merely an aspect of any of the others, or to being merely instrumental in the pursuit of any of the others" 105 . Therefore, there is no objective hierarchy amongst them, because "each one, when we focus on it, can reasonably be regarded as the most important"106. Two of these basic goods in particular may be linked to music: play (meaning specifically playing with sounds by performing musical pieces) and aesthetic experience (meaning both, making music and listening to it).

Play is a "large and irreducible element in human culture" involving "engaging in performances which have no point beyond the performance itself, enjoyed for its own sake" 107 . Play and aesthetic experience show some similarities, however they are distinguishable from one another, because play may be the occasion for aesthetic experience, whereas the latter does not necessarily need an action of one's own; it may be the inner experience of an appreciation of beauty ${ }^{108}$. It is interesting to note that Grisez, Boyle and Finnis stress the educational importance of these goods: in fact, in these researchers' opinion, play and aesthetic experience are, together with the other basic goods, aspects of the fulfillment of persons. Therefore, these scholars claimed, it is important that "children quickly come to see these goods as fields in which they can care for, expand and improve upon what they have received" 109 .

5. Concluding, it is noteworthy that, in the opinion of the Notre Dame Law School thinkers, play and aesthetic experience are both, gifts of nature, and therefore innate talents, and parts of a cultural heritage, and thus objects of human striving. The role of music teachers is therefore of an utmost importance: they can guide their pupils to understand and cherish listening to music and music playing, in such manner enjoying an aesthetic experience. By acting in this way, teachers will lead their pupils to develop an accomplished humanity, bridging the perceived gap between nature and culture.

\section{References}

1. Allain, Y.M. \& Christiany J. (2006). L'art des jardins en Europe. Paris: Citadelles and Mazenod

2. Annas, J. (1993). The Morality of Happiness. New York: Oxford University Press

3. Aquinas, T. (1988). Summa Theologica, trans. Fathers of the English Dominican Province, Hackett Publishing Co., Indianapolis, I-II, Q. 77, A. 2

\footnotetext{
${ }^{104}$ Russell Hittinger (1987), A Critique of the New Natural Law Theory, University of Notre Dame Press, Notre Dame, 40

${ }^{105}$ John Finnis (1980), Natural Law and Natural Rights, Clarendon Press, Oxford, 92

${ }^{106}$ Ibidem

${ }^{107}$ Curzon, Jurisprudence ..., 51

${ }^{108}$ Ibidem

${ }^{109}$ Grisez, Boyle, Finnis, Practical Principles..., 107
} 
4. Begbie J. (2013). Music, Modernity, and God. Essays in Listening, Oxford: Oxford University Press

5. Cohen, H.F. (1984). Quantifying Music. The Science of Music at the First Stage of the Scientific Revolution, 1580-1650, Springer-Science + Business Media, Dordrecht

6. Creese, D. (2010). The Monochord in Ancient Greek Harmonic Science. Cambridge: Cambridge University Press

7. Crowe, M. B. (1977). The Changing Profile of the Natural Law. New York: Springer

8. Curzon, P. (1993). Jurisprudence Lecture Notes. London: Cavendish Publishing Limited

9. Damschroder, D., Williams D. R. (1990). Music theory from Zarlino to Schenker. A Bibliography and Guide. Stuyvesant: Pendragon Press

10. Donald, J. A. (2015). Natural Law and Natural Rights. Retreived from http://jim.com/rights.html (accessed on 19 October 2015)

11. Finnis, J. (1980). Natural Law and Natural Rights. Oxford: Clarendon Press

12. Grisez, G., Boyle J., Finnis, J. (1987). Practical Principles, Moral Truth, and Ultimate Ends. The American Journal of Jurisprudence, 32, 99-151

13. Hittinger, R. (1987). A Critique of the New Natural Law Theory. Notre Dame: University of Notre Dame Press

14. Katz, R. (2009). A Language of its Own: Sense and Meaning in the Making of Western Art Music. Chicago: University of Chicago Press

15. Kuide, C. (1989). Man vs. Nature and Natural Man: One Aspect of the Concept of Nature in China and the West, in: Tang Yi-Jie, Li Zhen, George F. McLean (eds.), Man and Nature: The Chinese Tradition and the Future, (pp. 131-141). University Press of America, Lanham - New York - London

16. Levenson, T. (1994). Measure for Measure: A Musical History of Science. New York: Touchstone

17. Martìnez de Anguita, P. (2012). Environmental Solidarity. How Religions can Sustain Sustainability. New York: Routledge

18. Maxham, R. E. (1976). The contributions of Joseph Sauveur (1653-1716) to acoustics, [Dissertation], University of Rochester, 2 vol.

19. Richardson, T. (2007). The Arcadian Friends: Inventing the English Landscape Garden. London - Toronto - Sydney - Auckland - Johannesburg: Bantam Press

20. Tang, Y.J., Li, Z., McLean, G.F. (eds.) (1989). Man and Nature: The Chinese Tradition and the Future. Lanham - New York - London: University Press of America

21. Williams, M. (2006). Deforesting the Earth: From Prehistory to Global Crisis. An Abridgment. London: The University of Chicago Press

22. Willis, J. (2004). The Religion Book: Places, Prophets, Saints, and Seers. Canton: Visible Ink 